\title{
Pengembangan Media Bimbingan Cara Berinteraksi dengan Siswa Tunarungu dalam Bentuk Video Edukasi di SMK Inklusi
}

\author{
Defi Ratnasari*, Ella Faridati Zen, Muslihati \\ Universitas Negeri Malang, Jl. Semarang No. 5 Malang, Jawa Timur, Indonesia \\ *Penulis korespondensi, Surel: defiratna95@gmail.com
}

Paper received: 2-2-2021; revised: 20-2-2021; accepted: 27-2-2021

\begin{abstract}
This research goal to develop a media guidance how to interact with hearing impairment students in inclusive school. The research use model of Borg and Gall in 5 steps, namely (1) data collection, (2) planning, (3) designing the initial media format, (4) test validation, and (5) revision. The results from the validation test of material, media, and prospective users show that the average percentage of accuracy is 81.25 percent, utility is 86 percent, convenience is 86.67 percent, and attractiveness is 86.53 percent. These results indicate the media have been qualified in the acceptance to use in providing guidance service in inclusion school.
\end{abstract}

Keywords: interacting; deaf; inclusion; educational videos

\begin{abstract}
Abstrak
Penelitian ini bertujuan untuk mengembangkan media bimbingan cara berinteraksi dengan siswa tunarungu di sekolah inklusi. Metode penelitian yang digunakan adalah model penelitian Borg and Gall dalam 5 tahap yaitu (1) pengumpulan data, (2) perencanaan, (3) merancang format awal media, (4) uji validasi, dan (5) revisi. Hasil perolehan dari uji validasi ahli materi, media, dan calon pengguna menunjukkan rata-rata prosetase ketepatan sebesar 81,25 persen, kegunaan sebesar 86 persen, kemudahan sebesar 86,67 persen, dan kemenarikan sebesar 86,53 persen. Hasil tersebut menunjukkan bahwa media yang dikembangkan oleh peneliti telah memenuhi syarat keberterimaan dan layak digunakan sebagai media penunjang dalam memberikan layanan bimbingan di sekolah inklusi.
\end{abstract}

Kata kunci: berinteraksi; tunarungu; inklusi; video edukasi

\section{Pendahuluan}

Sekolah inklusi merupakan salah satu upaya pemerintah untuk memberikan hak yang sama dalam bidang pendidikan untuk anak berkebutuhan khusus. Hal ini diwujudkan dalam Peraturan Pemerintah No 70 Tahun 2009 Tentang Pendidikan Inklusi. Penyelenggaraan pendidikan inklusi ini diharapkan dapat membuat siswa berkebutuhan khusus belajar mengembangkan keterampilan sosial bersama teman-teman sebayanya dan dapat mengembangkan potensinya secara optimal. Selain itu, siswa yang reguler dapat belajar menghargai keanekaragaman, dan tidak bersikap diskriminatif terhadap anak berkebutuhan khusus.

Sekolah Menengah Kejuruan Negeri 2 Malang adalah salah satu sekolah penyelenggara pendidikan inklusi di Malang. Salah satu jenis kebutuhan khusus yang terdapat di sekolah ini adalah tunarungu. Siswa tunarungu adalah siswa yang mengalami gangguan pendengaran yang meliputi gradasi ringan, sedang, dan sangat berat yang dalam hal ini dikelompokkan menjadi dua golongan yaitu kurang dengar dan tuli, yang menyebabkan terganggunya proses perolehan informasi atau bahasa sebagai alat komunikasi (Atmaja, 2018). Terganggunya sistem pendengaran mempengaruhi perkembangan bahasa, kecerdasan, dan sosioemosional anak. 
Berdasarkan pengalaman peneliti pada saat melakukan kegiatan Pengenalan Lapangan Persekolahan, keberadaan anak tunarungu di kelas cenderung terisolir dan tidak banyak melakukan interaksi sosial dengan siswa reguler lainnya. Siswa tunarungu duduk sebangku dengan siswa sesama berkebutuhan khusus. Dalam proses pemberian layanan BK yang dilakukan secara berkelompok, siswa reguler mengerjakan tugas yang diberikan tanpa berdiskusi dengan siswa tunarungu.

Uraian tersebut di atas tidak sesuai dengan aspek perkembangan yang tertera pada Standar Kompetensi Kemandirian Peserta Didik (SKKPD) yang harus dicapai oleh siswa SMK, khususnya pada tataran ke sepuluh. SKKPD tataran kesepuluh yang perlu dicapai siswa adalah siswa mampu menghargai nilai-nilai kerjasama dan toleransi sebagai dasar untuk menjalin persahabatan dengan teman sebaya (Santoso, 2013).

Peran guru BK sangat penting untuk memfasilitasi siswa mencapai SKKPD khususnya tataran ke sepuluh dalam penelitian ini. Upaya yang dapat dilakukan oleh guru BK salah satunya adalah dengan menggunakan layanan bimbingan kelompok. Bimbingan kelompok merupakan proses pemberian bantuan yang diberikan pada individu dalam situasi kelompok (Romlah, 2018). Proses bantuan yang dimaksudkan adalah dengan memberikan informasi dan pengetahuan baru yang dibutuhkan oleh siswa.

Peneliti bermaksud mengembangkan media video edukasi cara berinteraksi dengan siswa tunarungu. Video edukasi tersebut merupakan media untuk memberikan layanan informasi kepada siswa reguler mengenai karakteristik, etika berinteraksi dan cara berkomunikasi dengan siswa tunarungu. Selain itu, peneliti juga mengembangkan buku panduan cara menggunakan video edukasi tersebut. Dengan adanya media ini siswa reguler dapat memahami cara berinteraksi yang tepat pada siswa tunarungu, sehingga kesehatan hubungan sosial dapat terjaga, iklim sekolah menjadi menyenangkan, dan siswa dapat meraih prestasi serta mengembangkan potensi secara optimal.

\section{Metode}

Metode penelitian pengembangan yang digunakan dalam penelitian ini adalah model Borg and Gall yang terdiri dari 10 tahap (1983), yaitu : (1) penelitian dan pengumpulan informasi awal, (2) perencanaan, (3) pengembangan produk awal, (4) uji coba produk, (5) revisi produk, (6) uji coba lapangan, (7) revisi produk, (8) uji lapangan, (9) revisi produk akhir, (10) desininasi dan implementasi.

Pada penelitian ini, prosedur penelitian model Borg and Gall tersebut disesuaikan dengan kebutuhan peneliti. Prosedur penelitian yang dilakukan peneliti adalah (1) pengumpulan data meliputi (a) menyebarkan angket need assessment untuk mengetahui keutuhan siswa, (b) melakukan kajian literature dengan mengkaji teori-teori yang revelan seta penelitian-penelitian terkait yang telah dilakukan, (2) langkah-langkah perencanaan yaitu (a) menentukan tujuan penelitian, (b) menyusun intrumen need assessment siswa, (c) mendesain video edukasi, (d) menyusun buku panduan, dan (5) menyusun instrument uji ahli. melakukan penelitian dan pengembangan sampai pada tahap ke lima yaitu revisi setelah menilai produk pada uji ahli, (3) video akan dikemas dengan animasi dan teks dan dubbing didalamnya untuk memperjelas pesan yang akan disampaikan, (4) uji coba produk dilakukan oleh dua ahli materi yaitu dosen Bimbingan dan Konseling, satu ahli media yaitu dosen Teknologi Pendidikan dan satu pengguna yaitu guru Bk SMKN 2 Malang (5) revisi dilakukan setelah mendapatkan penilaian dan catatan dari para ahli. 
Jenis data yang diperoleh dari penelitian ini adalah data kuantitatif dan kualitatif. Data kuantitatif diperoleh dari skor pengisian angket penilaian produk, yang dilakukan oleh ahli media dan ahli materi. Sementara, data kualitatif diperoleh dari hasil pengisian angket penilaian produk berupa catatan dalam angket tersebut. Teknik analisis data kuantitatif dilakukakan menggunakan analisis statistika deskriptif rata-rata dengan rumus menurut Arikunto (1993):

$$
\text { Persentase nilai rata }- \text { rata }(\%)=\frac{\text { Skor yang diobservasi }}{\text { Skor yang diharapkan }} \times 100 \%
$$

Setelah memperoleh hasil dalam bentuk persentase, kemudian diinterpretasikan dalam bentuk deskripsi. Interpretasi tersebut didasarkan pada tabel kriteria. Kriteria dari prosentase tersebut tercantum pada tabel berikut ini

Tabel 1 Interpretasi Penilaian Ahli

\begin{tabular}{cc}
\hline Perolehan Prosentase & Interpretasi \\
\hline $76-100 \%$ & Sangat Layak \\
\hline $56-75 \%$ & Cukup Layak \\
\hline $40-55 \%$ & Kurang Layak \\
\hline $0-39 \%$ & Tidak Layak \\
\hline
\end{tabular}

Sumber: Suharsimi Arikunto (1993)

\section{Hasil dan Pembahasan}

\subsection{Hasil}

Produk pertama dalam penelitian dan pengembangan ini adalah video edukasi. Video edukasi yang dikembangkan berisikan beberapa materi. Materi yang pertama adalah tentang karakteristik siswa tunarungu. Materi karakteristik ini meliputi karakteristik bahasa dan bicara, kecerdasan, sosial dan emosi. Materi tersebut disajikan secara ringkas dan ditambahkan gambar yang mendukung pesan dalam materi.

Materi dalam video edukasi meliputi karakteristik siswa tumraungu, etika berinteraksi dan cara berkomunikasi dengan siswa tunarungu. materi tersebut dikemas menggunakan animasi yang disesuaikan dengan karakteristik siswa SMK. Warna-warna dasar yang digunakan adala warna-warna pastel sehingga terkesan soft dan tidak mencolok. Jenis font yang dipilih sangat mudah dbaca. Dubbing ditambahkan sebagai penjelas materi yang ditampilkan dalam video.

Produk kedua dalam penilitian ini adalah buku pandun. Buku panduan disusun sebagai pedoan dalam menggunakan media video edukasi. Terdapat beberapa bagian dalam buku panduan ini. Bagian pertama pendahuluan berisikan rasional, tujuan dan sasaran bimbingan. Bagian kedua kajian teori. Pada bagian ini berisikan materi-materi yang sesuai dengan pengembangan produk yang dikaji secara sistematis dan komprehensif sebagai landasan peneliti dalam mengembangkan produk. Bagian terakhir dalam buku panduan adalah petunjuk penggunaan. Dalam bagian ini berisikan deskripsi produk, petunjuk umum, petunjuk khusu, dan rancangan lpemberian layanan. 
Buku panduan didesain dengan menggunakan warna biru sebagai warna utama. Warna biru dipilih karena memberikan kesan damai. Warna biru pada layout cover buku panduan dikombinasikan dengan warna putih dan hitam sebagai warna font. Selain itu juga ditambahkan gambar yang sesuai dengan judul buku panduan yaitu cara berinteraksi dengan siswa tunarungu. Gambar yang dipilih adalah adanya seorang perempuan yang berkomunikasi dengan laki-laki yang menggunakan alat bantu dengar dengan cara menggunakan bahasa isyarat.

Produk tersebut kemudian diujikan kepada ahli materi, media dan calon pengguna untuk mengetahui kualitasnya. Hasil dari uji ahli tersebut disajikan dalam tabel berikut.

Tabel 2. Hasil Penilaian Ahli dan Pengguna terhadap Video Edukasi dan Buku Panduan

\begin{tabular}{clccccc}
\hline No & Aspek & $\begin{array}{c}\text { Ahli Materi } \\
\text { Video } \\
\text { Edukasi }\end{array}$ & $\begin{array}{c}\text { Ahli Materi } \\
\text { Buku } \\
\text { Panduan }\end{array}$ & $\begin{array}{c}\text { Ahli } \\
\text { Media }\end{array}$ & $\begin{array}{c}\text { Uji } \\
\text { Pengguna }\end{array}$ & $\begin{array}{c}\text { Rata-rata } \\
\text { Nilai }\end{array}$ \\
\hline 1. & Ketepatan & $81,25 \%$ & $81,25 \%$ & $75 \%$ & $100 \%$ & $81,25 \%$ \\
\hline 2. & Kegunaan & $75 \%$ & $92,85 \%$ & $91,67 \%$ & $100 \%$ & $86 \%$ \\
\hline 3. & Kemudahan & $75 \%$ & $87,5 \%$ & $91,67 \%$ & $93,75 \%$ & $86,67 \%$ \\
\hline 4. & Kemenarikan & $83,33 \%$ & $75 \%$ & $91,67 \%$ & $93,75 \%$ & $86,53 \%$ \\
\hline
\end{tabular}

\subsection{Pembahasan}

Produk yang dikembangkan peneliti memperoleh skor rata-rata ketepatan sebesar $81,25 \%$. Hasil ini berarti produk yang dikembangkan peneliti sangat tepat. Produk ini sangat tepat untuk sekolah inklusi karena dirancang berdasarkan hasil need assessment. Need assessment merupakan hal yang dilakukan pertama dalam mengembangkan program bimbingan dan konseling. Hal ini dikarenakan assessment memiliki kedudukan sebagai dasar program layanan bimbingan dan konseling (Departemen Pendidikan Nasional, 2008). Need assessment dilakukan untuk mendapatkan informasi-informasi yang akurat mengenai kebutuhan program bimbingan dan konseling (Flurentin, 2016). Berdasarkan need assessment tersebut peneliti mengetahui secara pasti kebutuhan siswa terkait produk peneliti. Selain itu, peneliti melakukan kajian literatur terhadap teori-teori terkait sehingga peneliti dapat memilih dan merumuskan materi dengan tepat sesuai dengan kebutuhan. Melalui materi dalam video edukasi, siswa reguler dapat memahami karakteristik siswa tunarungu, ertika berinteraksi dan cara berkomunikasi dengan siswa tunarungu. Hal ini membuat siswa reguler mengetahui bagaimana harus bersikap saat berinteraksi dengan siswa tunarungu. Dengan demikian siswa reguler maupun siswa tunarungu dapat mencapai SKKPD tataran ke sepuluh tentang kematangan membina hubungan dengan teman sebaya.

Produk yang dikembangkan peneliti memperoleh skor rata-rata kegunaan sebesar 86\%. Hasil ini berarti produk yang dikembangkan peneliti sangat berguna. Produk ini sangat berguna untuk Guru BK, khususnya di sekolah inklusi untuk memberikan informasi dan edukasi kepada siswa reguler yang sebelumnya tidak pernah berinteraksi dengan siswa tunarungu. Hal ini dikarenakan produk peneliti digunakan untuk memberikan layanan informasi kepada siswa reguler mengenai karakteristik siswa tunarungu, etika berinteraksi dan cara berkomunikasi dengan siswa tunarungu. Layanan informasi diadakan untuk membekali siswa dengan pengetahuan tentang data dan fakta di bidang pendidikan sekolah, bidang pekerjaan, dan bidang perkembangan pribadi sosial, agar siswa mampu mengatur dan 
merencanakan kehidupannya (Flurentin, 2016). Produk video edukasi cara berinteraksi dengan siswa tunarungu dan buku panduan yang dikembangkan peneliti berguna untuk membekali siswa pada bidang pribadi dan sosialnya, sehingga siswa mampu menjalin hubungan sosial yang sehat dengan siswa tunarungu. Dengan demikian siswa juga akan mampu mencapai SKKPD tataran ke sepuluh mengani kematangan membina hubungan sosial dengan teman sebaya. Selain itu, produk peneliti juga dapat membantu terwujudnya tujuan penyelenggaraan pendidikan inklusi yang tercantum pada Peraturan Pemerintah No 70 Tahun 2009 Tentang Pendidikan Inklusi pasal 2 yaitu mewujudkan penyelenggaraan pendidikan yang menghargai keanekaragaman dan tidak diskriminatif bagi semua peserta didik.

Produk yang dikembangkan peneliti memperoleh skor rata-rata kemudahan sebesar 86,67\%. Hasil ini berarti produk yang dikembangkan peneliti sangat mudah. Mudah yang dimaksud dalam hal ini adalah mudah diakses, mudah digunakan dan mudah dipahami. Produk video edukasi sangat mudah diakses oleh guru BK maupun siswa karena peneliti menggunggahnya pada aplikasi Youtube. Youtube adalah situs web yang memungkinkan pengguna untuk mengungah, menonton dan berbagi video (Wikipedia, 2020). Video pada Youtube sangat mudah diakses menggunakan smartphone, computer atau laptop. Video edukasi tersebut juga sangat mudah digunakan oleh guru BK karena terdapat buku panduan yang untuk memandu guru BK dalam mengoperasikannya. Video edukasi dan buku panduannya juga sangat mudah dipahami oleh guru BK, namun terdapat kata yang sulit diapahami oleh siswa SMK pada video edukasi. Kata yang sulit dipahami tersebut telah direvisi oleh peneliti dengan menambahkan penjelasan tentang kata tersebut.

Produk yang dikembangkan peneliti memperoleh skor rata-rata kemenarikan sebesar 86,53\%. Hasil ini berarti produk yang dikembangkan peneliti sangat menarik. Produk video edukasi didesain dengan tampilan animasi yang disesuaikan dengan karakteristik siswa SMK yaitu dengan menampilkan karakter orang dewasa serta menggunakan icon dan infografis yang minimalis, transisi yang beragam, menggunakan animasi yang bergerak, serta teks ringkas yang menjadi gagasan pokok materi dipadukan dengan audio yang bersemangat, Video ini juga menggunakan dubbing untuk memperjelas materi yang ditampilkan pada video. Menurut Nursalim (2013) media video edukasi termasuk dalam kelompok media kelima yaitu multimedia. Multimedia merupakan gabungan dari audio dan visual, audio berasal dari musik maupun penjelasan secara lisan, sedangkan visual berasa dari gambar dan tulisan yang ditampilkan. Keduanya telah disinkronkan dan ditampilkan secara bersamaan. Multimedia dapat lebih menarik perhatian siswa karena kombinasi dari audio, visual dan gerakan, selain itu multimedia bersifat multisensorik, karena dapat merangsang banyak indera sehingga dapat mengarahkan perhatian ke tingkat retensi yang baik (Munir, 2012).

Berdasarkan uraian di atas maka data dipahami bahwa produk video edukasi cara berinteraksi dngan siswa tunarungu dan buku panduannya telah memenuhi syarat keberterimaan. Selain itu, juga dapat membantu mewujudkan tujuan penyelenggaraan sekolah inklusi serta memfasilitasi siswa mencapai SKKPD tataran ke sepuluh mengenai kematangan membina hubungan sosial dengan teman sebaya. Produk dapat digunakan guru BK di sekolah inklusi untuk memberikan layanan bimbingan pada siswa reguler kelas $\mathrm{X}$ sebagai bekal mereka dalam menjalani kehidupan sekolah yang berdampingan dengan siswa tunarungu. pemberian layanan bimbingan menggunakan produk ini dapat dilakukan dengan 
cara bimbingan klasikal atau bimbingan kelompok. Namun efektivitas produk ini belum diketahui secara pasti karena belum melalui uji efektivitas.

\section{Simpulan}

Berdasarkan pembahasan sebelumnya dapat disimpulkan bahwa produk video edukasi cara berinteraksi dengan siswa tunarungu dan buku panduannya telah memenuhi syarat keberterimaan dan layak digunakan sebagai media penunjang layanan bimbingan di sekolah inklusi. Media ini belum diuji efektifitasnya, untuk itu peneliti selanjutnya dapat menguji tingkat efektifitasnya. Peneliti selanjutnya juga dapat mengembangkan produk cara berinteraksi dengan siswa tunarungu dengan lebih kreatif, inovatif dan efektif.

\section{Daftar Rujukan}

Atmaja, J. R. (2018). Pedidikan dan Bimbingan Anak Berkebutuhan Khusus. Bandung: Remaja Rosdakarya.

Arikunto, S. (1993). Prosedur Penelitian Suatu Pendekatan Praktik (edisi revisi II, Cetakan Kesembilan). Jakarta: Penerbit Rineka Cipta

Borg, W. R \& Gall, M. D. (1983). Educational Research And Introduction. New York: Longman Inc.

Departemen Pendidikan Nasional. (2008). Penataan Pendidikan Profesional Konselor dan Layanan Bimbingan dan Konseling dalam Jalur Pendidikan Formal. Bandung: UPI.

Flurentin, E. (2016). Manajemen Bimbingan dan Konseling. Malang: Universitas Negeri Malang

Nursalim, M. (2013). Pengembangan Media Bimbingan dan Koseling. Jakarta: Erlangga

Munir. (2012). Multimedia Konsep \&Aplikasi dalam Pendidikan. Bandung: Alfabeta

Romlah, T. (2018). Teori dan Praktek Bimbingan Kelompok. Malang: Universitas Negeri Malang.

Peraturan Menteri Pendidikan Nasional Republik Indonesia No 70 Tahun 2009 Tentang Pendidikan Inklusif Bagi Peserta Didik yang Memiliki Kelainan dan Memiliki Potensi Kecerdasan dan/atau Bakat Istimewa. (Online) https://jdih.kemdikbud.go.id/arsip/Permendikbud_Tahun2009.pdf.

Santoso, D. B. (2013). Dasar-dasar Bimbingan dan Konseling. Malang: Universitas Negeri Malang.

Wikipedia. (2020). Youtube. Dari https://en.m.wikipedia.org/wiki/Youtube. 